\title{
KIMBERLITES OF THE MAN CRATON
}

\author{
EMW Skinner*, DB Apter $\downarrow$, C Morelli $\downarrow$, I Tomlinson $\downarrow$ and NK Smithson $\mathbf{s}$ \\ *Rhodes University, South Africa, DeBeers, South Africa, \$ Mano River Resources, Canada
}

\section{INTRODUCTION}

The kimberlites confined to the Man craton include at least three clusters of Jurassic aged kimberlites in Guinea, two clusters of Jurassic aged kimberlites in Sierra Leone, possibly two clusters of probable Jurassic age and one cluster now known to be about 800Ma in western Liberia (Figure 1). This cluster, close to the village of Weasua has not been previously described. The Jurassic kimberlites are considered to represent one province that extends from older kimberlites in Guinea to progressively slightly younger bodies in Sierra Leone and possibly younger still in Liberia. The Jurassic kimberlites occur as small pipes and prolific dykes whereas the Weasua Neoproterozoic kimberlites occur as mainly small pipes. Most of the pipes contain relicts of diatreme- in addition to hypabyssal-facies kimberlites and some also contain so-called transitional-facies kimberlites. The presence of diatreme-and transitional-facies kimberlites indicates that the pipes are classical, Class 1 types (Skinner and Marsh, this volume).

The scarcity of diatreme-facies, the presence of transitional-facies and the presence of only hypabyssalfacies in some pipes indicate that the pipes have been eroded down to the interface between the diatreme and root zones. By analogy with Class 1 kimberlites elsewhere it can be concluded that as much as $2 \mathrm{~km}$ may have been eroded since the Jurassic. On the other hand, on geomorphologic grounds it is concluded that the whole of the West African craton has undergone much less erosion. Most of the Jurassic kimberlites are mineralogically classified as phlogopite kimberlites. Relatively abundant groundmass opaque minerals often accompany these kimberlites. The Weasua kimberlites contain less phlogopite and much less groundmass opaque minerals. Most are mineralogically classified as mixed calcite-serpentine-phlogopite kimberlites. The Jurassic kimberlites are geochemically classified as mica-rich but $\mathrm{K}_{2} \mathrm{O}$-poor Group Ia kimberlites. The Weasua kimberlites are similarly classified.

Early crystallization of abundant phlogopite is considered to have had a profound affect on the emplacement processes of these kimberlites.

\section{DISTRIBUTION, AGE AND TECTONIC SETTING}

Most kimberlites in the world fall into individual complexes, elliptical clusters (measuring approximately $50 \mathrm{~km}$ long by $25 \mathrm{~km}$ wide) of petrographically similar kimberlites and larger provinces (of similar aged kimberlites) that in some cases may extend over thousands of kilometers. Clusters tend to be inclined to the province direction (re. Figure 1). Near surface structural patterns such as those discussed by Haggerty (1992) are thought to have had no control on the province or cluster directions. On the Man craton the Jurassic aged kimberlites are considered to represent one province. This extends from 153Ma (Fourie, Barton and Kiviets, 2000, unpub data) bodies in the southeastern cluster in Guinea, curving around to $146 \mathrm{Ma}$ (Fourie, Phillips and Kiviets, 1998, unpub data) bodies in the Koidu cluster in Sierra Leone. It then extends through the 140Ma (Andrews-Jones, 1968) kimberlites in the Tongo cluster, also in Sierra Leone, and probably ends in two undated clusters (Kumgbo and Mano Godua) in Liberia. The shape of the province is thought to relate to movement of the African plate first in a south- easterly direction and then in a northerly direction at the time of eruption. Based on acceptable known ages, the lithospheric plate into which these kimberlites were emplaced, is computed to have been moving at an average speed of about $25 \mathrm{~km}$ per 1 million years, initially in an east-south-east direction and then rotating at about $146 \mathrm{Ma}$ to a northerly direction. These plate movements relate to similar movements of the Kaapvaal plate as indicated by the age and position of Group II kimberlites in southern Africa.

The Weasua cluster in Liberia is oriented in a northsouth direction. Other possible Neoproterozoic clusters if they exist are likely to occur to the east or west of this cluster.

\section{PETROGRAPHY}

The Jurassic aged kimberlites occur as small pipes (up to 9ha.) and prolific dykes. The oldest pipes in the south-west cluster in Guinea, all the pipes in Liberia, and all the dykes are filled only by hypabyssal-facies kimberlite. Some of the slightly younger pipes in the 
northwest cluster in Guinea and in the Koidu cluster in Sierra Leone contain transitional- and diatreme-facies kimberlites in addition to hypabyssal-facies kimberlites. Most of the diatreme-facies kimberlites exhibit magmaclastic to pelletal textures but some have uniform textures (e.g. Koidu Pipe 2). All of the Koidu and most of the Guinea diatreme-facies specimens studied are tuffisitic kimberlite breccias (with $>15$ volume $\%$ country rock xenoliths) whereas some of the Guinea diatreme-facies are tuffisitic kimberlites (with $<15$ volume $\%$ xenoliths). The magmaclasts reach up to and greater than $10 \mathrm{~mm}$ in size. Besides altered olivine the magmaclasts contain abundant primary phlogopite. Importantly and contrary to previous studies (e.g. Taylor et al., 1994) none of the diatremefacies rocks contain calcite. The transitional-facies kimberlites represent those that occur at the interface between hypabyssal- and diatreme-zones (re. Skinner and Marsh, this volume). They commonly appear as though they have been texturally disturbed and are characterized by the presence of patches of almost unaffected hypabyssal-kimberlites and patches containing variable proportions of microlitic clinopyroxene. Most of the hypabyssal-facies kimberlites are macrocrystic and are mineralogically classified as phlogopite kimberlites, with phlogopite accounting for up to 34 volume $\%$ of the rock. These kimberlites are in most cases also accompanied by unusually large amounts of fine-grained euhedral groundmass opaque minerals up to 10 volume $\%$.

To date five small pipes of up to about 4ha and one dyke have been found in the Weasua cluster. On-going exploration results indicate that there are more kimberlites likely to be discovered in this cluster. Most of these bodies contain diatreme- in addition to hypabyssal-facies kimberlite and two (K1 and K2) also contain transitional-facies kimberlites. Diatreme-facies kimberlites are typically pelletal tuffisitic kimberlite breccias with small magmaclasts (generally $<2 \mathrm{~mm}$ in size). Some tuffisitic kimberlites also occur. Hypabyssal-facies kimberlites are all macrocrystic types with mixed (calcite-serpentine-phlogopite) mineralogies. Early crystallizing phlogopite accounts for about 18 volume $\%$ and ground-mass opaque minerals together with perovskite usually account for $<$ 3 volume $\%$.

\section{GEOCHEMISTRY}

Taylor et al. (1994) present a comprehensive geochemical study of some West African kimberlites. Kimberlites analyzed include samples from Guinea (pipes and dykes), Sierra Leone (mainly dykes and magmaclasts in pipes) and Liberia (mainly dykes in the Kumgbo cluster). Many of the samples are contaminated by crustal components (Contamination Index values of Clement, 1982 are greater than 1.6). Less contaminated specimens fall close to the field of Group IA southern African kimberlites as defined by Smith et al., 1985. This is so in spite of the fact that the kimberlites contain abundant phlogopite but $\mathrm{K}_{2} \mathrm{O}$ levels are relatively low (up to 4 but most $<2 \mathrm{wt} \%$ ). Two samples from Koidu have ${ }^{87} \mathrm{Sr} /{ }^{86} \mathrm{Sr}$ initial ratios that fall within the range of ${ }^{87} \mathrm{Sr} /{ }^{86} \mathrm{Sr}$ initial ratios for southern African kimberlites, but initial neodymium isotopic compositions fall close to bulk earth values, just below the ${ }^{143} \mathrm{Nd} /{ }^{144} \mathrm{Nd}$ range for Group I kimberlites (Taylor et al., 1994).

Five new samples of hypabyssal-facies kimberlite from pipes in the Weasua cluster, Liberia have been analyzed. These kimberlites are uncontaminated $(\mathrm{CI}<1.6)$. Most also fall within the geochemical field of non-micaceous Group IA kimberlites from South Africa and have $\mathrm{K}_{2} \mathrm{O}$ values $<2$ wt \%. Some have very low $\mathrm{CaO}$ values. They are tightly constrained by low $\mathrm{P}_{2} \mathrm{O}_{5}$ and $\mathrm{Ce}$. In terms of $\mathrm{Ce} / \mathrm{Sr}$ versus $\mathrm{Nb} / \mathrm{La}$ they fall within the South African Group I field and not within the Koidu-Aries field (Taylor et al., 1994) and are therefore geochemically distinct from the Koidu kimberlites.

\section{INDICATOR MINERALS}

The indicator mineral suite of the Man Craton kimberlites is well represented by the common indicator minerals: ilmenite, chromite, garnet (peridotitic and eclogitic) and clinopyroxene. Indicator mineral chemistry from the Koidu complex, predominantly from mantle xenoliths, has previously been studied by Tompkins and Haggerty, 1984 and Fung and Haggerty, 1995 which indicate a shield geotherm of $40 \mathrm{~mW} / \mathrm{m}^{2}$ and sampling from within the diamond stability field. Haggerty et al., 1979 reviewed indicator mineral compositions from western Liberia kimberlites where the full suite of typical kimberlitic indicators was recovered but with clinopyroxene and garnet being predominantly eclogitic. Stachel et al., 2002 presented indicator mineral inclusions in diamonds from Guinea being both eclogitic (dominantly) and peridotitic. Significant is the presence of majorite implying derivation from exceptional depths as well as inclusions suggesting metasomatic reenrichment of depleted lithosphere.

Our mineral chemistry data is consistent with that described previously. Garnet is of particular interest. Peridotitic garnets show derivation from a depleted lithospheric source; most are lherzolitic. An eclogitic garnet population (at least $5-10 \%$ per locality) is 
ubiquitous. Discrete grain garnet thermometry indicates a large proportion of the lherzolitic population has high termperatures (approaching adiabatic) while depleted grains are much cooler. The latter suggest a geotherm significantly cooler than $40 \mathrm{~mW} / \mathrm{m}^{2}$. In contrast to the other clusters the Neoproterozoic Weasua cluster is ilmenite poor, while garnet and spinel suggest a lithosphere source more depleted than that of the younger clusters.

\section{DEPTH OF EROSION SINCE EMPLACEMENT}

Evidence from the kimberlites themselves indicates that in parts there has been significant erosion (up to $2 \mathrm{~km}$ ) since the Jurassic. However this contrasts strongly with the geomorphologic and other geological evidence, which indicates that $<1 \mathrm{~km}$ of erosion has occurred.

The dominance of hypabyssal-facies kimberlites, the scarcity of diatreme-facies kimberlites and the rare occurrence of transitional-facies kimberlites in some pipes indicates that the kimberlites have in most cases been eroded down to below the root zones of pipes. In some cases they have been eroded to a position at the transition between root and diatreme and in other cases to the lower portions of the diatreme zone of classical Class 1 pipe types (re. Hawthorne, 1975). Preserved Class 1 pipes typically have craters of more than $500 \mathrm{~m}$ (e.g. as at Orapa Mine in Botswana, Field et al., 1997) and diatreme zones in excess of $1,5 \mathrm{~km}$ (e.g. as at the Premier mine in South Africa, Skinner and Marsh, this volume). In West Africa crater-facies kimberlites do not occur and only limited remnants of diatreme-facies kimberlites exist. This shows that entire crater zones and most of the diatreme zones have been removed by erosion. By analogy with Class 1 pipes in southern African mines it is concluded that in Guinea more than $2 \mathrm{~km}$ of erosion has occurred in the area of the Droujba pipe but just less than $2 \mathrm{~km}$ has been eroded in the area of the Banankoro pipes. The Droujba pipe is free of diatreme- and transition-facies kimberlite whereas the Banankoro pipes do contain remnants of diatreme- and transition-facies kimberlite. In Sierra Leone all of the Koidu pipes appear to contain remnants of diatremeand transition-facies kimberlites whereas in the Kumbgo and Mano Godua clusters in Liberia most kimberlites are dykes with a few small pipes. Here erosion may have exceeded $2 \mathrm{~km}$ even though these kimberlites are likely to be slightly younger than those in Sierra Leone and Guinea. The Weasua pipes in Liberia, contain remnants of diatreme- and transitionalfacies even though they are probably much older than the Kumgbo kimberlites. However they are located in the Kpo mountain range, so probably have been better preserved.

Geomorphologically West Africa is characterized by a 'basin-and-swell' pattern, which, on a continental scale is situated at low altitudes (generally below 500masl). This pattern contrasts strongly with the southern-central part of Africa which lies at much higher elevations of over 1000masl (Brown \& Girdler, 1985, Doucouré et al., 2000). It is likely that the whole of western Africa as well as parts of northern Africa have always been at low level in spite of several phases of uplift and warping, especially during Gondwana break-up. The final break-up occurred in the Cretaceous with the formation of the Atlantic Ocean, and extensive marine transgressions. At the end of the Cretaceous, the whole African continent underwent a major phase of uplift and sea regression and it is only from the early Tertiary that the continent remained above sea level. By the end of the Albian at c.100Ma, West and North Africa (AfroArabia) became a tectonically quiet continent. This tectonic stability, which persisted for more than $70 \mathrm{M}$ years, provided the conditions for the development of an extensive, low elevation, deeply weathered surface, the so-called African Surface (Burke \& Dewey, 2002) on which have developed extensive laterite deposits. The survival of these laterites suggests that little erosion has occurred since their deposition.

\section{PIPE SIZES}

The known pipes on the Man craton are small relative to other Class 1 kimberlites in Africa. The small size is considered to be due partly to the early crystallization of abundant phlogopite, which ties up dissolved water in the phlogopite molecule prior to decompression and crystallization induced exsolution (re. Skinner and Marsh, this volume). As a result the residual magma becomes relatively poorer in water and the amount of water available to participate in the exsolution process is reduced. The amount of $\mathrm{P} \Delta \mathrm{V}$ energy generated is reduced and the severity of the exsolution induced explosion is diminished. Consequently the explosive eruption is less intense compared with the eruptions of common mica-poor, Group I, Class 1 kimberlites and the resulting pipes are relatively smaller. The relatively small size may also in part be due to extensive erosion but the evidence of limited erosion provided by geomorphologic constraints questions this view.

\section{CONCLUSION}

Two provinces of kimberlites are recognized on the Man craton; a larger one of Jurassic age consisting of six separate clusters and extending from Guinea, through Sierra Leone and into Liberia plus a smaller 
one of Neoproterozoic age present only in Liberia. Most of the Jurassic kimberlites are phlogopite- and opaque mineral-rich, Group IA types whereas the Neoproterozoic kimberlites are mixed calciteserpentine-phlogopite, Group IA types. Both provinces have some small pipes filled by remnants of diatremeand transitional-facies kimberlites plus hypabyssalfacies kimberlites. These pipes would be classed as Class 1 or classical pipes as defined by Skinner and Marsh (this volume).

\section{REFERENCES}

Andrews-Jones, D.A., 1968. Petrogenesis and geochemistry of the rocks of the Kenema district, Sierra Leone $(\mathrm{PhD}$ thesis abs.); LeedsUniv, England.

Brown, C., Girdler, R.W., 1985. Interpretation of Africa gravity and its implications for breakup of the continents, J. Geophys. Res. 85, 6443-6455.

Burke, K.A.C., Dewey, J.F., 2002. Global Tectonics and the African Continent. Wits Univ., School of Geosciences, course notes, 35-42.

Clement, C.R., 1982. A comparative geological study of some major kimberlite pipes in the northern Cape and Orange Free State. Unpul. PhD thesis, Univ. Cape Town.

Doucouré, C.M., de Wit, M.J., Reeves, C.V., 2000. Towards a gravity map of Gondwana. J. Afr. Earth Sci., 31, I 1, 195-204.

Field, M., Gibson, J.G., Wilkes, T.A., Gobabotse, J., Khutjwe, P. 1997. The geology of the Orapa A/K1 kimberlite Botswana: Further insight into the emplacement of kimberlite pipes. Russian Geol. and Geophys. 38, 1, 24-39.

Field, M., Scott Smith, B.H. 1999. Contrasting geology and near-surface emplacement of kimberlite pipes in Southern Africa and Canada $7^{\text {th }}$ Int. Kimb. Conf. Cape Town, 1, 214-237.

Fung, A.T., Haggerty, S.E., 1995. Petrography and mineral compositions of eclogites from the Koidu Kimberlite Complex, Sierra Leone. J. Geophys. Res. 100, B10, 20451-20473.

Haggerty, S.E., Bence, R.J., McMahon, B.M., 1979. Kimberlites in Western Liberia: Part 3 Mineral Chemistry. In $2^{\text {nd }}$ Intern. Kimberlite Symp., Extended Abstracts, 2, Cambridge.

Haggerty, S.E. 1992. Diamonds in West Africa: Tectonic setting and kimberlite productivity. Russian Geol. Geophys. 33,10, 35-49.

Hawthorne, J.B. 1975. Model of a kimberlite pipe. Phys. Chem. Earth, 9, 1-15.
O’Brien, H.E., Tyni, M., 1999. Mineralogy and geochemistry of kimberlites and related rocks from Finland. $7^{\text {th }}$ Int Kimb. Conf. Cape Town, 2, 625-636.

Skinner, E.M.W., Marsh, J.S., this volume. Kimberlite eruption processes.

Statchel, T., Harris, J.W., Aulbach, S., and Deines, P., 2002. Kankan diamonds (Guinea) III: $\delta^{13} \mathrm{C}$ and nitrogen characteristics of deep diamonds. Cont. Min. Pet. 142. $465-475$.

Smith, C.B., Gurney, J.J., Skinner, E.M.W., Clement, C.R., Ebrahim, N., 1985. Geochemical character of Southern African Kimberlites: A new approach based on isotopic constraints. Trans. Geol. Soc. S.A., 88, 267-280.

Taylor, W.R., Tompkins, L.A., Haggerty, S.E. 1994. Comparative geochemistry of West African kimberlites: Evidence for a micaceous end member of sublithospheric origin. Geochim. et Cosmochim Acta $58,19,4011-4037$.

Tompkins, L.A., Haggerty, S.E. 1984. The Koidu kimberlite complex, Sierra Leone: Geological setting, petrology and mineral chemistry. Proceedings $3^{\text {rd }}$ Int. Kimb. Conf. Clermont Ferrand, I, 83-105.

Contact: EMW Skinner, PO Box 2216, Grahamstown 6140, South Africa, E-mail: e.m.w.skinner@ru.ac.za 


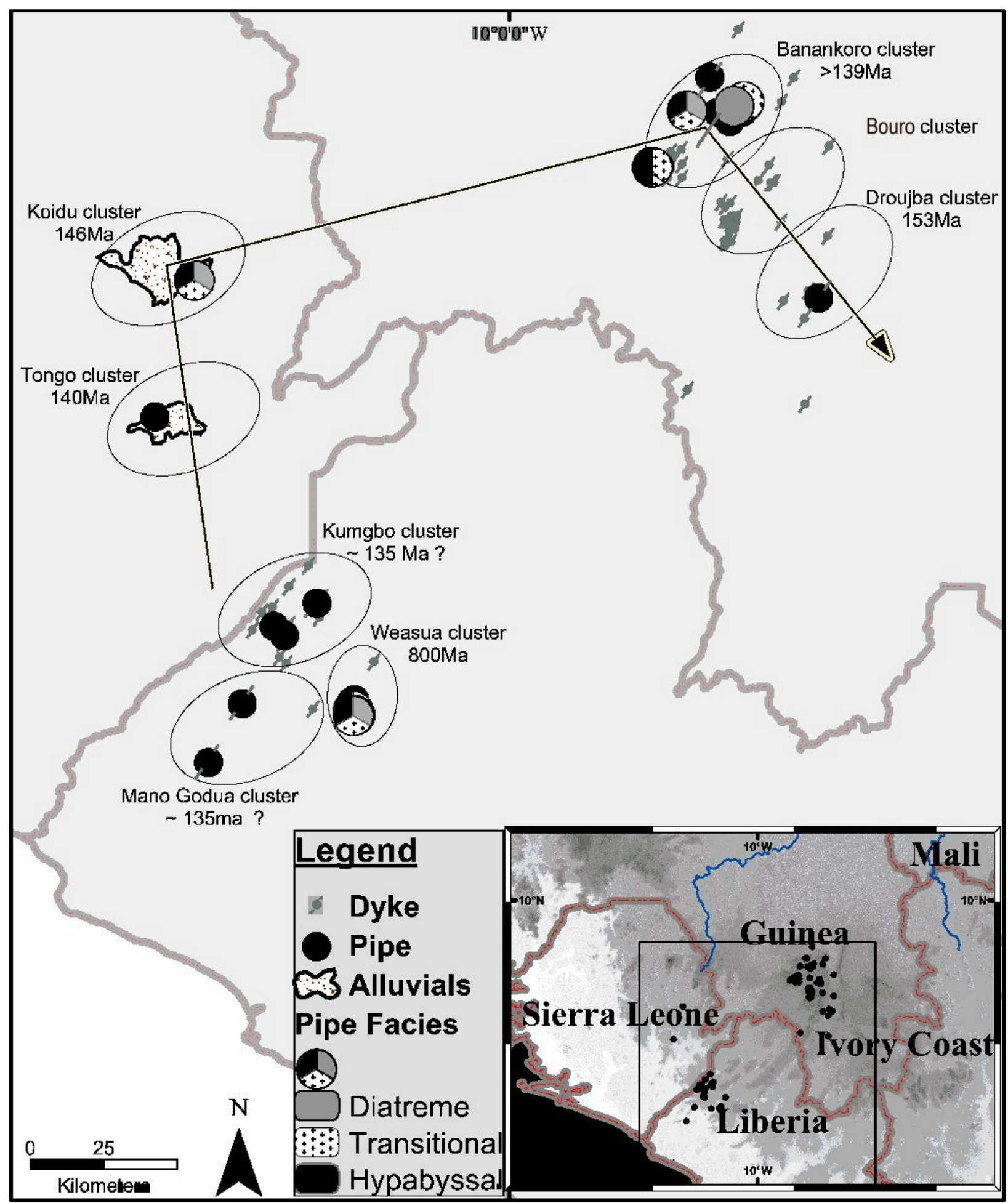

Figure1: Locality map 